Brazilian Journal of Microbiology (2009) 40: 433-438

ISSN 1517-8382

\title{
DEVELOPMENT OF A POLYMERASE CHAIN REACTION ASSAY FOR THE DETECTION OF PSEUDORABIES VIRUS IN CLINICAL SAMPLES
}

\author{
Lester J. Pérez ; Heidy Díaz de Arce \\ Grupo de Virología, Centro Nacional de Sanidad Agropecuaria. San José de las Lajas, La Habana, Cuba. \\ Submitted: June 25, 2008; Returned to authors for corrections: July 23, 2008; Approved: May 03, 2009.
}

\begin{abstract}
Aujeszky's disease, also known as pseudorabies causes severe economic losses in swine industry and affects the pig husbandry all over the world. The conventional diagnostic procedure is time-consuming and false-negative results may occur in submissions from latently infected animals. The development, optimization and evaluation of a polymerase chain reaction (PCR) assay are presented for the diagnosis of pseudorabies infection. This assay was based on the amplification of a highly conserved viral $\mathrm{gD}$ gene fragment. PCR products of the expected size were obtained from PRV strains. Non-specific reactions were not observed when a related herpesvirus, other porcine DNA genome viruses and uninfected cells were used to assess PCR. The analytical sensitivity of the test was estimated to be $1.34 \mathrm{TCID}_{50} / 50 \mathrm{uL}$. The analysis of tissue homogenate samples from naturally infected animals proved the potential usefulness of the method for a rapid disease diagnosis from field cases. A rapid, sensitive and specific PCR-based diagnostic assay to detect pseudorabies virus in clinical samples is provided.
\end{abstract}

Key words: Aujeszky's disease; pseudorabies infection, PCR assay.

\section{INTRODUCTION}

Aujeszky's disease, also known as pseudorabies leads to severe economic losses in swine industry and affects the pig husbandry all over the world. The etiological agent of this disease is suid herpesvirus type 1, usually named pseudorabies virus (PRV), a pantropic alphaherpesvirus which causes fatal infections in baby pigs, respiratory disease and poor growth in fattening pigs and reproductive disorders in adults $(2,8,13)$. The virus principally affects pigs, which are considered to be the natural host for PRV and the reservoir of the virus in nature, but also infects a broad range of wild and non-porcine mammals with the important exception of higher-order primates (8).

The viral agent following a primary replication can establish latent infection and develops a latency-reactivation infection which allows its perpetuation in pig populations $(10,12,15)$.

Traditionally, PRV detection is based on direct virus isolation followed by confirmation using immunofluorescence, immunoperoxidase or neutralization tests with specific antiserum (2). However, this method is time-consuming and false negative results may occur in submissions from latently infected animals (14).

*Corresponding Author. Mailing address: Grupo de Virologia, Centro Nacional de Sanidad Agropecuaria, San Jose de las Lajas, La Habana, Cuba. Email: lesterjosue@censa.edu.cu 
Pérez, L.J. et al.

The polymerase chain reaction (PCR) can be used to identify PRV genomes in secretions or organ samples and although some PCR assays for PRV detection with different sensitivities have been reported $(3,7,9,15)$ there is no standard procedure recommended so far (2).

This paper describes the development, optimization and performance assessment of a rapid and highly sensitive PCR test for detection of pseudorabies virus.

\section{MATERIALS AND METHODS}

\section{Viruses and cells}

PRV reference strain NIA-3, PRV Cuban isolate V208 (4) and porcine parvovirus (PPV) isolated from piglets were grown and titrated in porcine kidney cell line (PK-15) (ATCC CCL 33) following standard procedures. Bovine herpesvirus 1 (BHV1) strain E8 was propagated in Madin-Darby Bovine Kidney cells (MDBK, ATCC CCL 22) by standard protocol. DNA extracted from porcine circovirus type 2 vaccine strain (PCV2) (Suvaxyn ${ }^{\circledR}$ PCV2 Fort Dodge) and from african swine fever virus (ASFV) kindly supplied by OIE Reference Laboratory for African Swine Fever, CISA/INIA, Valdeolmos, Spain were also used in the specificity assays.

\section{Clinical specimens from field samples}

In order to evaluate the efficiency of the extraction method and for the assessment and optimization of the PCR assay in clinical samples, a collection of nine tissue homogenates samples (spleen, liver and lymph nodes, 10\% in PBS) from natural PRV infections (5) from the Virology Laboratory of CENSA (La Habana, Cuba) was used. Seven virus-negative tissues samples from clinically healthy animals were also included.

\section{Extraction of RNA and DNA}

Total DNA extraction from animal tissues homogenates (spleen, liver and lymph nodes, 10\% in PBS) and from supernatants of infected cell cultures, was carried out from $100 \mu \mathrm{L}$ amounts of samples with Wizard® Genomic DNA Purification Kit, (Promega, Madison, WI, USA) following manufacturer's protocol recommendations. DNA was resuspended in $10 \mu \mathrm{L}$ of nuclease free water (Promega, Madison, WI, USA)

\section{Oligonucleotide primers and restriction endonuclease selection}

PRV specific primers were designed using the Oligo 6.31 program, (Molecular Biology Insights, Inc., USA) based on highly conserved nucleotide region of the viral $\mathrm{gD}$ glycoprotein. Nucleotide sequences available in GenBank (AY217094, M1400, M1400, strain Fa AY196984, strain LA AY196984, strain Min-A AY169694, strain Kaplan AJ271966, mutant strain gDiE AJ271967) were aligned using Clustal W 1.8 software and manually examined previously in the search of highly conserved region. A BLAST search at National Center for Biotechnology Information (NCBI) site (http://www.ncbi.nlm.nih.gov) was performed using blastn algorithm for calculating sequence similarity with primers selected as query sequences against nucleotide databases of different herpesvirus and random nucleotide sequences. Primers sequences, genome positions and the size of PCR products are shown in Table 1.

Table 1. Primers designed for the specific amplification of the viral gD glycoprotein gene of the PRV genome.

\begin{tabular}{llll}
\hline Primer & Nucleotide Sequence (5'-3') & Genome position (5'-3') & Amplicon length (pb) \\
\hline PRV-sense & GGT GGA CCG GCT GCT GAA CGA & $280-300$ & $455 \mathrm{pb}$ \\
PRV-antisense & GCT GCT GGT AGA ACG GCG TCA & $734-714$ & \\
\hline
\end{tabular}

${ }^{a}$ PRV strain (GenBank accession no. AY217094) 
Sequence analysis of the PRV genome region delimited by PRV sense/PRV antisense primer pair allowed to locate a Sma I restriction endonuclease site, splitting the amplicon in two fragments of 241 and $214 \mathrm{bp}$, that was conserved in the PRV nucleotide sequences analysed. The Sma I restriction endonuclease site was used for additional specificity confirmation of the amplification products.

\section{Optimization of PCR conditions}

Optimization of the critical parameters of the PCR for the detection PRV was performed, including concentration of reagents and PCR cycling parameters. The different concentration of magnesium chloride $(\mathrm{MgCl} 2)$, and primers were evaluated according to the manufacture's protocol (Promega PCR Core Systems TB 254 bulletin/Promega, Madison, USA).

For the determination of optimal parameters was considered the amplicons's intensity visualized by electrophoresis on $2.0 \%$ agarose gel in TBE buffer $(90 \mathrm{mM}$ Tris-borate, $2 \mathrm{mM}$ EDTA). Thus, the optimal concentration of $\mathrm{MgCl} 2$ and primers were $1.5 \mathrm{mM}$ and $0.6 \mu \mathrm{M}$ respectively (data not shown).

The annealing temperature and number of cycles were determined experimentally. The best results were obtained with a temperature of $68^{\circ} \mathrm{C}$ for 35 cycles. Annealing and elongation were performed at the same step of each cycle at $68^{\circ} \mathrm{C}$ for $2 \mathrm{~min}$. This was possible due to the high annealing temperature of the primers pair designed and contributes to the reaction efficiency.

\section{PCR assay}

The PCR reaction was performed in $50 \mu \mathrm{L}$ volumes, in which the reaction mixture contained $2 \mu 1$ of DNA, 1x GoTaq Green Master Mix (Promega) [200 $\mu$ M of each dNTP, $1.5 \mathrm{mM}$ $\mathrm{MgCl} 2(\mathrm{pH} 8.5)]$ and $0.6 \mu \mathrm{M}$ of each primer. The cycling protocol consisted of an initial denaturation at $94^{\circ} \mathrm{C}$ for 2 min, then 35 cycles which consisted of denaturation at $94^{\circ} \mathrm{C}$ for $15 \mathrm{sec}$., annealing and extension at $68^{\circ} \mathrm{C}$ for $2 \mathrm{~min}$. The sample was then heated at $72^{\circ} \mathrm{C}$ for $7 \mathrm{~min}$ for a final extension. Negative controls were run with each test. Agarose gel electrophoresis was used to detect PCR products.

\section{Restriction enzyme analysis}

Analysis with Sma I restriction endonuclease of the PRV amplicon was performed in a $20 \mu \mathrm{L}$ volume reaction, using $5 \mu \mathrm{L}$ of the amplification products, previously purified by Wizard ${ }^{\circledR}$ PCR Preps DNA Purification System (Promega), and $5 \mathrm{U}$ of enzyme. Reactions were incubated for at least $4 \mathrm{~h}$ at $25{ }^{\circ} \mathrm{C}$. Restriction fragments were analysed by electrophoresis on a $2 \%$ agarose gel.

\section{RESULTS}

PCR experiments were performed on serial ten-fold dilutions of a viral suspension of PRV isolate V208 with a titer of $10^{6.3} \mathrm{TCID}_{50} / \mathrm{mL}$ in animal tissues homogenate sample from a healthy pig that was negative by the proposed PCR, in order to determine the PCR's detection limit. The analytical sensitivity of the test was consistently observed to be 1.34 $\mathrm{TCID}_{50} /$ reaction volume (Fig. 1 ).

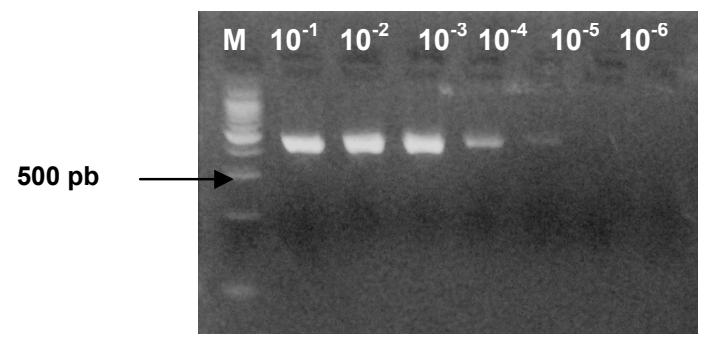

Figure 1. PCR sensitivity assay for PRV detection. DNA's extracted from serial dilutions, in pig tissue homogenate samples, of a PRV strain viral suspension with a titer of $10^{6.3} \mathrm{TCID}_{50} / \mathrm{mL}$ were employed under reaction conditions above described. M: molecular weight marker 100pb (Promega) 
A PCR product from the expected size was obtained when DNA from PRV strain NIA-3 and Cuban PRV V208 isolate (4) were used as templates for amplification reactions. Specificity of the PRV amplicons was furthermore confirmed by Sma I restriction endonuclease analysis which generated the two expected fragments of 241 and 214 bp in length (Fig. 2).

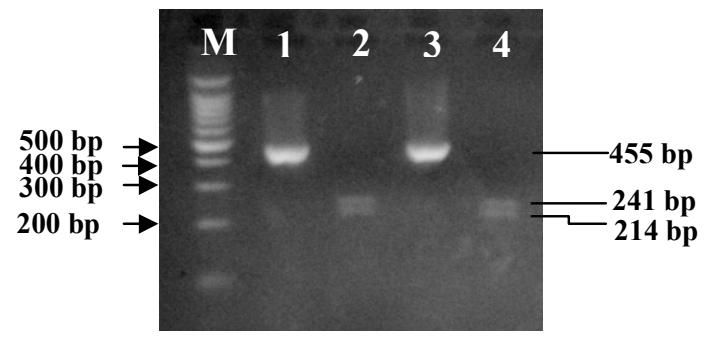

Figure 2. Sma I restriction endonuclease analysis of amplification products of PRV NIA-3 and PRV V208 strains. M: molecular weight marker 100pb (Promega), PRV NIA-3 (1 and 2), PRV V208 (3 and 4). Lanes 1 and 3 are amplification products, Lanes 2 and 4 are amplification products after digestion with Sma I

Moreover, the viral genomes of a related herpesvirus and other DNA genome porcine viruses as follow: HVB1, PPV, CVP2 and PPA, were assayed, giving not amplification signal (Fig.3). Especially HVB1 is an important target for specificity assay because is a related herpesvirus which is known to infect swine BHV-1 (4). Finally, nucleic acids from tissue homogenates samples derived from seven healthy pigs, and a non infected PK-15 cell line were also tested showing no positive products (data not shown).

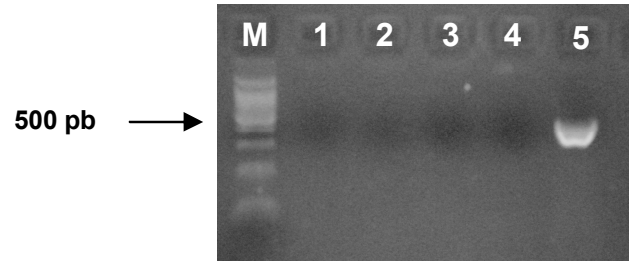

Figure 3. PCR specificity assay for PRV detection. M: molecular weight marker $100 \mathrm{pb}$ (Promega), lane 1-IBR; lane 2-PPV; lane 3PCV2; lane 4- ASFV; lane 5-PRV
Each one of the nine tissue field samples from pigs diagnosed as PRV infected based on clinical signs and laboratory methods yielded the corresponding PRV amplified product when analyzed. Seven tissue samples from clinically healthy animals were negative for PCR amplification (data not shown).

\section{DISCUSSION}

The serious reduction to the pig production caused by Aujeszky's, disease can be explained by the pathogenesis picture of PRV infections. The virus primarily replicates in the respiratory tract, spreads along cranial nerves to the brains and via lymph and blood to internal organs, with the reproductive organs being affected. Replication in the respiratory tract, central nervous system and reproductive organs is responsible for pathological changes causing different disorders (13).

In general, PRV infections must be considered in the differential diagnosis of respiratory, reproductive and nervous disorders. For instance, Aujeszky's disease must be confused in cases of reduced fertility with parvovirus infection, CSF, PRRS, and leptospirosis (6). Under typical conditions of intensive swine production, several clinically similar viral diseases can occur which require laboratory differential diagnosis. A rapid and accurate diagnosis of PRV infection is important for the initiation of appropriate control strategies. Since the rapid detection of infected animals would reduce the potential transmission of the viruses to uninfected herds avoiding the spread of the diseases (11).

The polymerase chain reaction (PCR) is a rapid tool that can be used no only to detect acutely PRV infected pigs but it is the recommended test for detect PRV latent infection. The trigeminal ganglion is the most consistent site for virus isolation, although latent virus is usually difficult to culture or even impossible $(1,13)$ and PCR is the method recommended to detect viral genome present in this site. 
The PCR for PRV genome detection is also an important method in screening pig specimens collected for xenotransplantation to increase the safety of organ transplantation (7) and to detect viral infection in a wide spectrum of species reported to be susceptible to PRV, through either natural or experimental infections (8).

The nucleotide sequence amplified in this study corresponds to a $455 \mathrm{bp}$ fragment in the gD gene of the PRV genome (16). This gene codes for an envelope glycoprotein named $\mathrm{gD}$ which plays and important role in binding cellular receptors and is critical for virus replication in different organs (12). This region was highly conserved for all reported genomes as shown by aligning of these sequences. Also, the BLAST search against nucleotide databases of different herpesvirus and random nucleotide sequences revealed this region is very specific for PRV genomes.

Mostly, the specificity of PCR is regulated by the length of the oligonucleotide and/or the temperature of annealing of the primer to the template. The intrinsic attributes of the two designed primers, such as equivalent and high Tm lead to and optimal PCR temperature, determined empirically, that assures "non-specific" amplification and consequently "nonreduction" in yield of the desired product. The possibility to perform annealing and elongation in one single step of the thermal profile contributed to the specificity and the efficiency of the assay and allowed the use of a very fast PCR program.

The assay specificity was demonstrated by the absence of amplifications in all heterologous viruses evaluated and in tissue samples derived from seven healthy pigs. In particular, the ability of the PCR assay to distinguish PRV from HVB1, a related alphaherpesvirus, which infects swine, is critical for reliable PRV diagnosis.

The assay proved to be very sensitive due to as little as $1.34 \mathrm{TCID}_{50} / 50 \mathrm{uL}$ was detected. In addition, positive amplifications were obtained in all the tissue samples, from PRV natural infected pigs, evaluated. The analysis directly from clinical samples from naturally infected animals proved the potential usefulness of the method for a rapid disease diagnosis from field cases.

The PCR assay described here provides a rapid, highly sensitive, and cost-effective laboratory diagnosis for pseudorabies infections.

\section{RESUMO}

\section{Desenvolvimento de um ensaio de Reação de Polimerase em Cadeia para detecção do vírus da pseudo-raiva em amostras clínicas}

A doença de Aujeszky, também conhecida como pseudoraiva, causa perdas econômicas graves na indústria suína e afeta a criação de suínos em todo o mundo. O procedimento de diagnóstico convencional é demorado, podendo ocorrer resultados falso-negativos em animais infectados de forma latente. Este estudo apresenta o desenvolvimento, otimização e avaliação de um ensaio de Reação de Polimerase em Cadeia para o diagnóstico da pseudo-raiva. $\mathrm{O}$ ensaio baseou-se na amplificação do fragmento genético viral $\mathrm{gD}$ altamente conservado. Os produtos da PCR de tamanho esperado foram obtidos a partir de isolados de PRV. Não foram observadas reações inespecíficas quando foram testados herpes-vírus relacionados, outros vírus DNA de suínos e células não infectadas. A sensibilidade analítica estimada do teste foi 1,34 $\mathrm{TCID}_{50} / 50 \square \mathrm{L}$. A análise de homogenatos feitos com tecidos de animais naturalmente infectados mostrou que o método é útil para o diagnóstico rápido da doença no campo, sendo um ensaio rápido, sensível e específico para detectar o vírus da pseudo-raiva em amostras clinicas.

Palavras-chave: doença de Aujeszky, pseudo-raiva, ensaio de PCR. 
Pérez, L.J. et al.

\section{REFERENCES}

1. Alemán, N.; Quiroga, M.I.; López-Peña, M.; Vázquez, S.; Guerrero, F.H.; Nieto, J.M. (2001). Induction and inhibition of apoptosis by pseudorabies virus in the trigeminal ganglion during acute infection of swine. J. Virol. 75, 469-479.

2. Aujeszky's Disease. Chapter 2.2.2. (2004). In Manual of Standards for Diagnostic Tests and Vaccines. Paris: World Organization for Animal Health, 245-257.

3. Cao, S.; Chen, H.; Zhao, J.; Lu, J.; Xiao, S.; Jin, M.; Guo, A.; Wu, B.; He, Q. (2005). Detection of porcine circovirus type 2, porcine parvovirus and porcine pseudorabies virus from pigs with postweaning multisystemic wasting syndrome by multiplex PCR. Vet. Res. Commun. 29, 263-269.

4. Derbyshire, J.B.; Caplan, B.A. (1976). The isolation and characterization of a strain of infectious bovine rhinotracheitis virus from stillbirth in swine. Can J Com Med. 40, 252-256.

5. Díaz, J.C.; Castell, S.; Barrera, M. (2006). Diagnosis of Aujeszky's disease virus infection in samples of doubtful etiology. Rev. Salud. Anim. 28, 1, 36-39.

6. Greiser-Wilke, I.; Blome, S.; Moennig, V. (2007). Diagnostic methods for detection of Classical swine fever virus-Status quo and new developments. Vaccine, 25, 5524-5530.

7. Hans, N.; Glorieux, S.; Favoreel, H.; Pensaert, M. (2007). Cell biological and molecular characteristics of pseudorabies virus infections in cell cultures and in pigs with emphasis on the respiratory tract. Vet. Res. 38, 229-241

8. Harding, M.J.; Prud'homme, I.; Rola, J. (1997). Specificity and Nucleotyping Studies of a gp5O-Based Polymerase Chain Reaction Assay for Detection of Pseudorabies Virus. Can. J. Vet. Res. 61, 157160 .
9. Kluge, J.P.; Beran, G.W.; Hill, H.T.; Platt, K.B. (1992). Pseudorabies. In: Leman, A.D.; Straw, B.; Glock, R.D.; Mengeling, W.L.; D'Allaire, S.; Taylor, D.J. (Eds), Diseases of Swine. Iowa State University Press, Ames, IA.

10. Lee, C.S.; Moon, H.J.; Yang, J.S.; Park, S.J.; Song, D.S.; Kang, B.K.; Park, B.K. (2005). Multiplex PCR for the simultaneous detection of pseudorabies virus, porcine cytomegalovirus, and porcine circovirus in pigs. J. Virol. Methods, 139; 39-43

11. Maes, R.; Sussman, M.; Vilnis, A.; Thacker, B. (1997). Recent development in latency and recombination of Aujeszky's disease (Pseudorabies) virus. Vet. Microbiol. 55, 13-27.

12. McNulty, M.S. (2003). Aujeszky's disease in fattening pigs. Vet Rec. 153(11), 340 .

13. Mettenleiter, T.C. (2000). Aujeszky's disease (Pseudorabies) virus: the virus and molecular pathogenesis-State of the art. Vet. Res. 31, 99-115.

14. Nauwynck, H.; Glorieux, S.; Favoreel, H.; Pensaert, M. (2007). Cell biological and molecular characteristics of pseudorabies virus infections in cell cultures and pigs with emphasis on respiratory tract. Vet. Res. 38, 229-41.

15. Romero, C.H.; Meade, P.N.; Homer, B.L.; Shultz, J.E.; Lollis, G. (2003). Potential sites of virus latency associated with indigenous pseudorabies viruses in feral swine. J. Wildl. Dis., 39(3), 567-575.

16. Ros-Bascuñana, C.; Björnerot, L.; Ballagi-Pordhy, A.; Robertsson, JA.; Belak, S. (1997). Detection of pseudorabies virus genomic sequences in apparently uninfected 'single reactor' pigs. Vet. Microbiol. 55, 37-47.

17. Wu, D.Y.; Ugozzoli, L.; Pal, B.K.; Qian, J.; Wallace, R.B. (1991). The effect of temperature and oligonucleotide primer length on the specificity and efficiency of amplification by the polymerase chain reaction. DNA Cell Biol. 10(3), 233-238. 